\title{
Informing and inspiring
}

OPEN

Richard M. Ransohoff, MD

Correspondence to

Dr. Ransohoff:

Ransohr@ccf.org

Neurol Neuroimmunol

Neuroinflammation

2014;1:e23; doi: 10.1212/

NXI.0000000000000023
This second issue of Neurology ${ }^{\circledR}$ Neuroimmunology \& Neuroinflammation incorporates examples of the types of reports that incarnate our mission: to inform and inspire the community of neuroinflammation and neuroimmunology researchers. Tran et al. ${ }^{1}$ report a phase I trial of LINGO antibodies, inaugurating clinical development of remyelination therapy for multiple sclerosis (MS), and the attainment of this goal is discussed by Brugarolas and Popko, ${ }^{2}$ authorities on the relevant basic science. Radke et al. $^{3}$ describe 2 adult patients with a histologic variant of dermatomyositis, 1 in whom formation of secondary lymphoid-like structures is observed. Lymphoneogenesis is a poorly understood feature of chronic inflammatory disorders, but it could potentially be unraveled by applying knowledge of immune system ontogeny. Mir et al. ${ }^{4}$ report evidence for chronic oxidative stress in the tissues of patients with progressive MS. Oxidative stress is a prominent topic of speculation in discussions of the pathogenesis of MS progression, so it's doubly rewarding to have tangible evidence for this process coming from living patients. Furthermore, this observation may provide a foundation for monitoring hoped-for treatment trials for this obdurate condition. Li et al. ${ }^{5}$ describe how to monitor macular edema in a patient with MS receiving fingolimod, thereby enabling the continuation of a therapeutic modality considered by the treating physicians to be useful for this clinical circumstance. A novel presentation of neurotransmitter receptor antibody-mediated neurologic disease comes from Zuliani et al. ${ }^{6}$ : adult patients with new-onset epilepsy were found to harbor glycine receptor antibodies. Zhang et al. ${ }^{7}$ describe an unprecedented case of paraneoplastic cerebellar disease and voltage-gated calcium channel antibodies in an individual with a neuroendocrine (Merkel cell) cancer. Prüss and coworkers ${ }^{8}$ report a case which suggests another potential mechanism for inducing NMDA receptor antibody-mediated encephalitis. This contribution adds insight into a mysterious, tantalizing condition.

Two reports extending our knowledge of myelin autoimmunity come from Shetty et al. ${ }^{9}$ and
Varrin-Doyer et al. ${ }^{10}$ Their topic is the immune response to myelin oligodendrocyte glycoprotein (MOG) in mice and humans. It's quite a surprise to realize that new insights still remain to be unveiled from investigating MOG autoimmunity. Scientists familiar with the experimental autoimmune encephalomyelitis (EAE) model of the inflammatory aspect of MS will be familiar with MOG autoimmunity and may consider the subject closed. MOG occupies a place of pride in the long search for pathogenically relevant antigens in MS: unlike other myelin protein antigens, MOG is localized to the outer surface of myelin, where it's available for engagement by antibodies. Indeed, MOG was first discovered in follow-up studies of a monoclonal antibody that reacted to rodent cerebellar white matter, and MOG antibodies were later shown to worsen T-cell-mediated EAE. ${ }^{11,12}$ Based in part on this feature of MOG (its exposure at myelin surfaces), investigation of the fine detail of the autoimmune response focused on the $\mathrm{N}$-terminal portions of the molecule. The entire ectodomain (residues 1-125) could elicit a T-cell-dependent antibody response in mice. Furthermore, the disease variant initiated by immunizing with $\mathrm{MOG}_{1-125}$ was severe and was somewhat unusually antibody dependent. ${ }^{11}$ Different from myelin basic protein, another historically significant myelin antigen, MOG is localized exclusively in CNS myelin, a compelling counterpart to MS, which affects CNS but not peripheral nervous system myelin.

In a parallel development, mice on the C57BL/6 (B6) background were found to develop reliable monophasic EAE upon immunization with $\mathrm{MOG}_{35-55}$. This peptide immunization became the preferred workhorse for investigations of CNS autoimmunity because the vast majority of gene-targeted knockout mice were backcrossed onto the B6 background. Regardless of the wisdom of or initial motivations for selecting this genetic strain both for neuroscience and for immunologic studies, once a large number of knockout mice on the B6 background became available, it was prohibitively restrictive to try to conduct

From the Neuroinflammation Research Center, Mellen Center for MS Treatment and Research; and Cleveland Clinic Lerner College of Medicine, Cleveland, $\mathrm{OH}$.

Go to Neurology.org/nn for full disclosures. Funding information and disclosures deemed relevant by the author, if any, are provided at the end of the editorial.

This is an open access article distributed under the terms of the Creative Commons Attribution-Noncommercial No Derivative 3.0 License, which permits downloading and sharing the work provided it is properly cited. The work cannot be changed in any way or used commercially. 
studies in any other mouse strain, unless overwhelming rationale was present. Doubly transgenic mice carrying a transgenic $\mathrm{T}$-cell receptor recognizing $\mathrm{MOG}_{35-55}$ and an immunoglobulin heavy chain encoding an MOG antibody developed spontaneous EAE despite adequate numbers and activity of regulatory $\mathrm{T}$ cells (reviewed in reference 13). As of this writing, a PubMed search for $\mathrm{MOG}_{35-55}$ yields 420 hits.

Shetty et al. and Varrin-Doyer et al. were undeterred by this history and sought reactivity to the intracellular C-terminal portion of MOG. Their immunologic logic was impeccable: $\mathrm{CD}^{+}{ }^{+} \mathrm{T}$-cell antigens come from processing of proteins within dendritic cells or other antigen-presenting cells: the localization of the antigen is irrelevant for $\mathrm{CD}^{+}{ }^{+} \mathrm{T}$-cell reactivity. Their research yielded pay dirt: several robust antigenic peptides were identified by clever adaptation of classical methods (using dye dilution to detect antigen-driven proliferation in response to overlapping peptides across the full extent of MOG). Furthermore, one of the peptides elicited severe EAE, which could furthermore be transferred by antigen-reactive $\mathrm{T}$ cells, proving pathogenicity. In addition, "their" peptides evoked a much stronger recall response after whole-protein immunization than did $\mathrm{MOG}_{35-55}$, showing that they'd identified an immunodominant determinant. There were 2 useful "take home" messages: first, myelin autoantigens need not be encephalitogenic (because only 1 of 3 different immunogenic peptides caused disease); and second, MOG reactivity lies in the C-terminal portion of the molecule.

Next it was time to translate their findings to human subjects, and the findings were gratifying. In particular, 3 peptides identified in mice (MOG p119-130, p181195, and p186-200) elicited HLA-DR-dependent responses from human $\mathrm{T}$ cells and one peptide provoked a Th17-biased cytokine profile from reactive $\mathrm{T}$ cells.

The data carry general implications for pathogenesis and treatment of autoimmune disease. As the authors note, tolerizing strategies focus on defined antigens, so it's crucial to identify all relevant antigens. This work adds to plausible target MOG antigens. Moreover, MOG antibodies were recently detected ${ }^{14}$ in studies of patients with seronegative neuromyelitis optica (those lacking aquaporin- 4 antibodies). The story of MOG autoimmunity, which long seemed settled, marches on.

\section{DISCLOSURE}

Richard M. Ransohoff conducts research supported by the NIH, the National MS Society, the DOD, the Alzheimer's Association, the Guthy-Jackson Foundation, Williams Family Foundation for MS Research, ChemoCentryx, Lundbeck, Teva, Novartis, Genzyme, and Biogen-Idec. Dr. Ransohoff has received fees for preclinical consulting or honoraria for academic presentations from Amgen, Genentech, Roche, Novartis,
Biogen-Idec, and Pfizer. He serves on scientific advisory, medical advisory, or safety monitoring boards for ChemoCentryx and Vertex. He receives an honorarium from the AAN as the Editor of Neurology: Neuroimmunology \& Neuroinflammation. Go to Neurology.org/nn for full disclosures.

\section{REFERENCES}

1. Tran JQ, Rana J, Barkhof F, et al. Randomized phase I trials of the safety/tolerability of anti-LINGO-1 monoclonal antibody BIIB033. Neurol Neuroimmunol Neuroinflammation 2014;1:e18; doi: 10.1212/NXI.0000000000000018.

2. Brugarolas P, Popko B. Remyelination therapy goes to trial for multiple sclerosis. Neurol Neuroimmunol Neuroinflammation 2014;1:e26; doi: 10.1212/NXI.0000000000000026.

3. Radke J, Pehl D, Aronica E, et al. The lymphoid follicle variant of dermatomyositis. Neurol Neuroimmunol Neuroinflammation 2014;1:e19; doi: 10.1212/NXI.0000000000000019.

4. Mir F, Lee D, Ray H, Sadiq SA. CSF isoprostane levels are a biomarker of oxidative stress in multiple sclerosis. Neurol Neuroimmunol Neuroinflammation 2014;1:e21; doi: 10.1212/NXI.0000000000000021.

5. Li V, Kane J, Chan HHL, Hall AJ, Butzkeuven H. Continuing fingolimod after development of macular edema: a case report. Neurol Neuroimmunol Neuroinflammation 2014;1:e13; doi: 10.1212/NXI.0000000000000013.

6. Zuliani L, Ferlazzo E, Andrigo C, et al. Glycine receptor antibodies in 2 cases of new, adult-onset epilepsy. Neurol Neuroimmunol Neuroinflammation 2014;1:e16; doi: 10.1212/NXI.0000000000000016.

7. Zhang C, Emery L, Lancaster E. Paraneoplastic cerebellar degeneration associated with noncutaneous Merkel cell carcinoma. Neurol Neuroimmunol Neuroinflammation 2014;1:e17; doi: 10.1212/NXI.0000000000000017.

8. Prüss H, Hoffmann C, Stenzel W, Saschenbrecker S, Ebinger M. A case of inflammatory peripheral nerve destruction antedating anti-NMDA receptor encephalitis. Neurol Neuroimmunol Neuroinflammation 2014;1:e14; doi: 10.1212/NXI.0000000000000014.

9. Shetty A, Gupta SG, Varrin-Doyer M, et al. Immunodominant T-cell epitopes of MOG reside in its transmembrane and cytoplasmic domains in EAE. Neurol Neuroimmunol Neuroinflammation 2014;1:e22; doi: 10.1212/NXI.0000000000000022.

10. Varrin-Doyer M, Shetty A, Spencer CM, et al. MOG transmembrane and cytoplasmic domains contain highly stimulatory T-cell epitopes in MS. Neurol Neuroimmunol Neuroinflammation 2014;1:e20; doi: 10.1212/ NXI.0000000000000020.

11. Wekerle H, Kojima K, Lannes-Vieira J, Lassmann H, Linington C. Animal models. Ann Neurol 1994;36(suppl): S47-S53.

12. Linington $\mathrm{C}$, Lassmann H. Antibody responses in chronic relapsing experimental allergic encephalomyelitis: correlation of serum demyelinating activity with antibody titre to the myelin/oligodendrocyte glycoprotein (MOG). J Neuroimmunol 1987;17:61-69.

13. Ransohoff RM. A mighty mouse: building a better model of multiple sclerosis. J Clin Invest 2006;116:2313-2316.

14. Willison HJ, Linington C. Antibodies to MOG in NMO: a seasoned veteran finds a new role. Neurology 2012;79: 1198-1199. 


\section{Neurology $^{\odot}$ \\ Neuroimmunology \& Neuroinflammation}

Informing and inspiring

Richard M. Ransohoff

Neurol Neuroimmunol Neuroinflamm 2014;1;

DOI 10.1212/NXI.0000000000000023

This information is current as of August 28, 2014

Updated Information \&

Services

References

Permissions \& Licensing

Reprints including high resolution figures, can be found at:

http://nn.neurology.org/content/1/2/e23.full.html

This article cites 14 articles, 10 of which you can access for free at: http://nn.neurology.org/content/1/2/e23.full.html\#\#ref-list-1

Information about reproducing this article in parts (figures,tables) or in its entirety can be found online at:

http://nn.neurology.org/misc/about.xhtml\#permissions

Information about ordering reprints can be found online: http://nn.neurology.org/misc/addir.xhtml\#reprintsus

Neurol Neuroimmunol Neuroinflamm is an official journal of the American Academy of Neurology.

Published since April 2014, it is an open-access, online-only, continuous publication journal. Copyright $@$ 2014 American Academy of Neurology. All rights reserved. Online ISSN: 2332-7812.

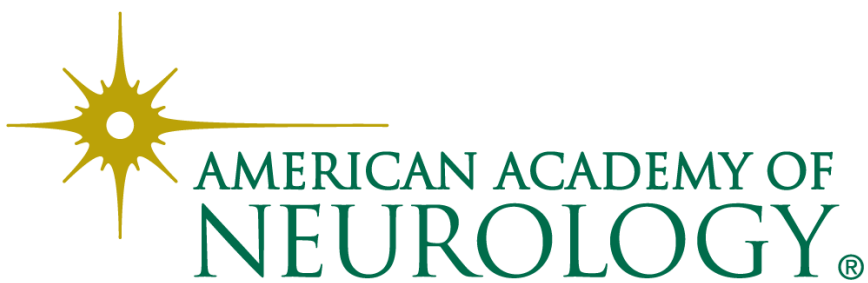

